\title{
Oxpentifylline and cetiedil citrate improve deformability of dehydrated sickle cells
}

\author{
J STUART, P C W STONE, Y Y BILTO, A J KEIDAN \\ From the Department of Haematology, Medical School, University of Birmingham, Birmingham
}

SUMMARY Erythrocytes from 14 patients with homozygous sickle cell anaemia were treated with the calcium ionophore A23187 to induce loss of cellular potassium and water. The dehydrated cells showed a decrease in filterability (loss of deformability) through pores of $5 \mu \mathrm{m}$ diameter. Oxpentifylline and cetiedil citrate, which preserve erythrocyte cation and water content, had a significant $(p<0.01)$ protective effect against loss of deformability at a concentration of $1 \mu \mathrm{mol} / 1$. Oxpentifylline showed no adverse effect on the rheology, morphology, or haemolysis of sickle cells at concentrations up to $500 \mu \mathrm{mol} / \mathrm{l}$. Drugs that act on the erythrocyte membrane to maintain cell hydration are of potential rheological benefit in sickle cell anaemia.

The dense erythrocytes in patients with sickle cell anaemia are depleted of potassium ${ }^{1}$ and the associated loss of cell water contributes to their high mean cell haemoglobin concentration (MCHC). ${ }^{2-4}$ Increase in MCHC greatly increases the intracellular polymerisation of haemoglobin $\mathrm{S}(\mathrm{HbS})^{5}$ so that polymer may form at arterial oxygen tension. ${ }^{6}$

It is not known whether sickle cells lose potassium and water by direct leakage through a cell membrane distorted by extended spicules of polymer, ${ }^{7}$ or by opening the Gardos ${ }^{8}$ channel in response to transient increases in cytoplasmic calcium before this cation becomes compartmentalised in membrane vesicles. ${ }^{9} \mathrm{Al}-$ ternatively, young sickle cells that swell in response to a fall in $\mathrm{pH}$ at sites of ischaemia may lose potassium and water via the recently described volume sensitive $\mathrm{KCl}$ cotransport system. ${ }^{1011}$ Whatever the cause of their dehydration, the deformability of sickle cells is adversely affected by the increase in $\mathrm{MCHC}^{1213}$ and is substantially improved by rehydration. ${ }^{12} 14$

Oxpentifylline is a dimethyl xanthine derivative that binds reversibly to erythrocyte membranes and has been shown to increase walking distance in patients with atherosclerotic intermittent claudication. ${ }^{15}$ We have recently shown that the drug prevents loss of potassium and therefore water from normal (haemoglobin AA) erythrocytes that had been loaded with calcium using the ionophore A23187. ${ }^{16}$ The same experimental model has now been used to study the action of oxpentifylline on sickle cells from

Accepted for publication 21 December 1987
14 patients with homozygous (SS) sickle cell anaemia. Oxpentifylline was compared, at equimolar concentrations, with the iminoester cetiedil citrate which alsog changes the cation content of sickle cells by increasing passive influx of sodium or preventing loss of potas sium induced by calcium gain. ${ }^{17-20}$ Intravenous infusion of cetiedil has been shown to shorten the duration of vaso-occlusive crisis. ${ }^{21}$

\section{Material and methods}

The 14 SS patients were in the asymptomatic steady state. Heparinised venous blood was washed through Imugard IG 500 cotton wool (Terumo Corporation, Tokyo, Japan), using $20 \mathrm{mmol} / \mathrm{l}$ HEPES buffered saline (HBS) of osmolality $290 \mathrm{mmol} / \mathrm{Kg} \mathrm{H}_{2} \mathrm{O}$ and $\mathrm{pH}$ $7 \cdot 4$, to give a suspension of leucocyte free washed erythrocytes. ${ }^{22}$ Passage through cotton wool does not selectively remove irreversibly sickled cells ${ }^{23}$ or other dense sickle cells, ${ }^{24}$ and HBS has been shown not to change the MCHC of sickle cells. ${ }^{25}$

Filtration of oxygenated sickle cells through polycarbonate membranes with pores of $5 \mu \mathrm{m}$ diameter and 10-11 $\mu \mathrm{m}$ length (Nuclepore Corporation, Pleasanton, California, USA) was measured at $37^{\circ} \mathrm{C}$ using a Hemorheometre (IMH, $95470 \mathrm{St}$ Witz, France) to give an index of filtration (IF) corrected for erythrocyte count. ${ }^{16}$ This index is the ratio of the flow resistance of erythrocytes suspended in HBS at a cell count of $0.3 \times 10^{12} / 1$ to that of HBS alone, and is expressed as relative resistance rather than absolute units; an increase in IF indicates loss of erythrocyte 


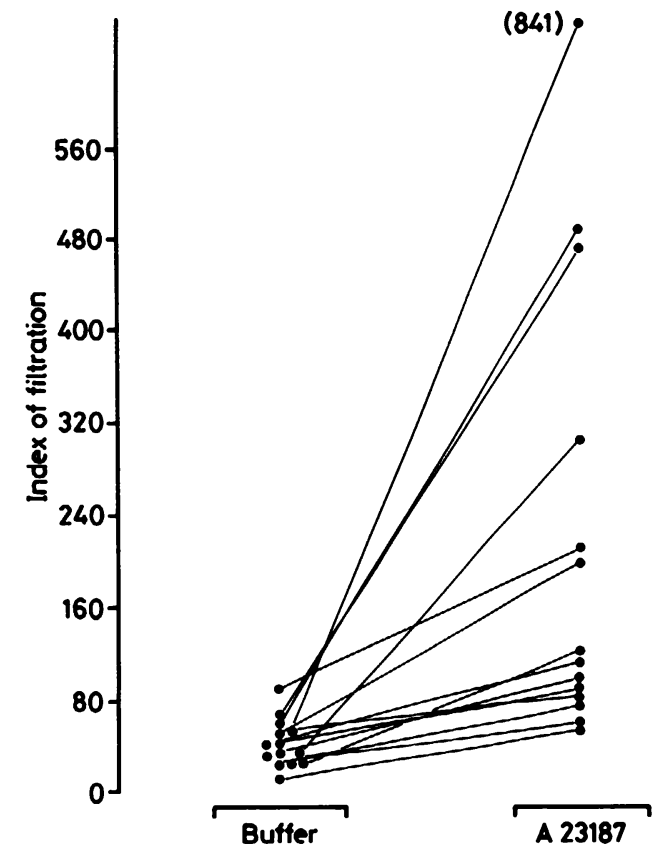

Fig 1 Index of filtration (IF) of sickle cells from 14 patients after incubation of cells for 60 minutes in control buffer and in buffer with calcium ionophore A23187. Increase in IF indicates loss of filterability.

deformability. A pore diameter of $5 \mu \mathrm{m}$ rather than 3 $\mu \mathrm{m}$ was used as this enhances sensitivity to cytoplasmic viscosity and therefore to cytoplasmic hydration. ${ }^{2627}$ The polycarbonate membranes were cleaned by ultrasonication in $1 \% \mathrm{w} / \mathrm{v}$ sodium dodecyl sulphate and reused. ${ }^{28}$

A stock solution of the calcium ionophorc A23187 (Calbiochem brand, Behring Diagnostics, La Jolla, California, USA) in absolute ethanol $(1.9 \mathrm{mmol} / \mathrm{l})$ was stored at $-40^{\circ} \mathrm{C}$ and diluted in ice cold HBS immediately before use. Oxygenated sickle cells $\left(0.3 \times 10^{12} / 1\right)$ were incubated for 60 minutes at $37^{\circ} \mathrm{C}$ in control buffer (HBS, $\mathrm{CaCl}_{2} 100 \mu \mathrm{mol} / \mathrm{l}, \mathrm{MgCl}_{2} 2$ $\mathrm{mmol} / \mathrm{l}$, glucose $10 \mathrm{mmol} / \mathrm{l}$ ) and in control buffer plus A23187. As there was considerable individual variation in response to ionophore a concentration of A23187 (range 0.5 $1.3 \mu \mathrm{mol} / \mathrm{l}$ ) which increased the IF value by at least two-fold, was selected for each patient. Oxpentifylline or cetiedil citrate, at final drug concentrations of $0,1,10,100$ and $500 \mu \mathrm{mol}$, was added to the cell suspensions at $37^{\circ} \mathrm{C}, 15$ minutes before the addition of ionophore. Oxpentifylline was dissolved in HBS immediately before use. A stock solution of cetiedil citrate in absolute ethanol (125 $\mathrm{mmol} / \mathrm{l}$ ) was stored at $-40^{\circ} \mathrm{C}$.

Morphology of incubated erythrocytes was as-

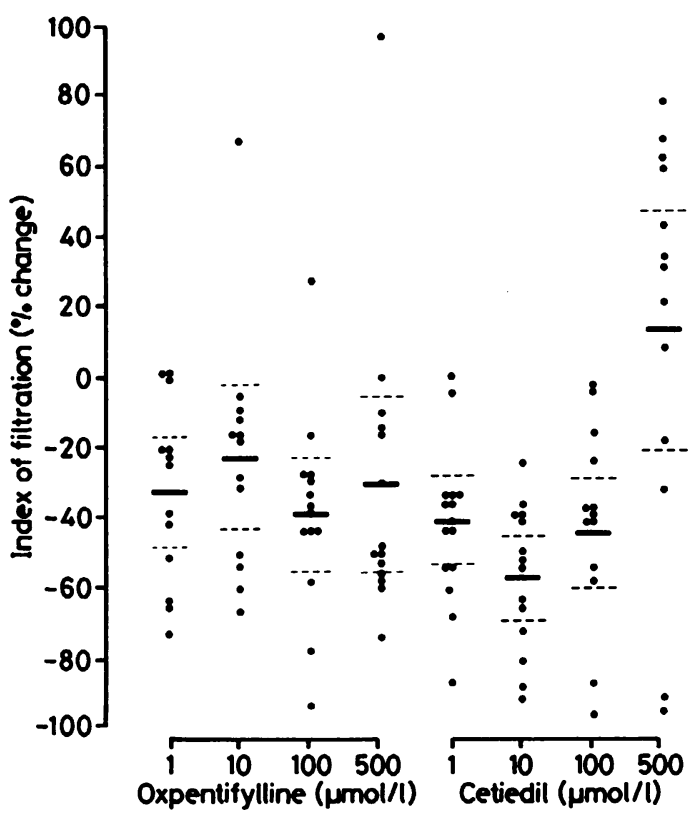

Fig 2 Index of filtration of sickle cells after incubation for 60 minutes in buffer containing A23187 ionophore and either oxpentifylline or cetiedil citrate. Results (mean and 95\% confidence interval for 14 patients) expressed as percentage change from IF values for sickle cells incubated with A23187 (fig 1) but without either drug.

sessed by interference microscopy on 300 oxygenated cells fixed with $1.25 \% \mathrm{w} / \mathrm{v}$ glutaraldehyde in HBS, using the Bessis classification ${ }^{29}$ for stomatocytes and echinocytes. Cells whose length was twice their width or those which had angular contours were counted as irreversibly sickled cells (ISC). ${ }^{30}$ The extent of haemolysis of the erythrocyte suspensions was assessed from the supernatant haemoglobin concentration, measured spectrophotometrically using tetramethyl benzidine. Significance (two tail) was determined by Wilcoxon's non-parametric signed rank test for paired data.

\section{Results}

Calcium loading of sickle cells using A23187 ionophore caused an increase in IF (loss of filterability) after 60 minutes compared with cells in control buffer (fig 1). As there was considerable variation between patients in the extent to which A23187 increased IF, the effects of oxpentifylline and cetiedil citrate were expressed as pcrcentage change from the IF value after incubation with A23187 alone (fig 2). All four concentrations of oxpentifylline significantly improved IF $\quad(10 \mu \mathrm{mol} / \mathrm{l}, \quad \mathrm{p}<0.05$; other concentrations, $p<0.01)$ and caused no change in erythrocyte mor- 
Table Effect of oxpentifylline and cetiedil on erythrocyte morphology and haemolysis after incubation with A23187 ionophore for 60 minutes (mean and $S E M, n=14$ )

\begin{tabular}{|c|c|c|c|c|}
\hline & $\begin{array}{l}\text { Stomatocytes } \\
(\%)\end{array}$ & $\begin{array}{l}\text { Echinocytes } \\
(\%)\end{array}$ & $\begin{array}{l}\text { Irreversibly } \\
\text { sickled cells } \\
(\%)\end{array}$ & $\begin{array}{l}\text { Supernatant } \\
\text { haemoglobin } \\
(\mathrm{mg} / \mathrm{l})\end{array}$ \\
\hline Control buffer & $\begin{array}{c}4.9 \\
(1.9)\end{array}$ & $\begin{array}{c}8 \cdot 1 \\
(1 \cdot 4)\end{array}$ & $\begin{array}{c}9 \cdot 7 \\
(2 \cdot 1)\end{array}$ & $\begin{array}{l}97 \\
(7)\end{array}$ \\
\hline A23187 & $\begin{array}{c}3 \cdot 5 \\
(1 \cdot 2)\end{array}$ & $\begin{array}{l}19 \cdot 1 \dagger \\
(4.9)\end{array}$ & $\begin{array}{c}8 \cdot 3 \\
(2 \cdot 2)\end{array}$ & $\begin{array}{r}101 \\
(4)\end{array}$ \\
\hline \multicolumn{5}{|c|}{ Oxpentifylline: } \\
\hline $1 \mu \mathrm{mol} / 1$ & $\begin{array}{c}3 \cdot 7 \\
(1 \cdot 0)\end{array}$ & $\begin{array}{l}17 \cdot 4 \\
(3 \cdot 0)\end{array}$ & $\begin{array}{c}9 \cdot 3 \\
(2 \cdot 5)\end{array}$ & $\begin{array}{r}107 \\
(8)\end{array}$ \\
\hline $10 \mu \mathrm{mol} / 1$ & $\begin{array}{c}4 \cdot 2 \\
(1 \cdot 1)\end{array}$ & $\begin{array}{l}16 \cdot 3 \\
(4 \cdot 1)\end{array}$ & $\begin{array}{c}8 \cdot 6 \\
(2 \cdot 0)\end{array}$ & $\begin{array}{c}114 \\
(7)\end{array}$ \\
\hline $100 \mu \mathrm{mol} / 1$ & $\begin{array}{c}5 \cdot 3 \\
(1 \cdot 7)\end{array}$ & $\begin{array}{l}11.4 \\
(2.9)\end{array}$ & $\begin{array}{l}9 \cdot 3 \\
(2 \cdot 0)\end{array}$ & $\begin{array}{l}99 \\
(3)\end{array}$ \\
\hline $500 \mu \mathrm{mol} / 1$ & $\begin{array}{l}4 \cdot 5 \\
(2 \cdot 9)\end{array}$ & $\begin{array}{l}13.0 \\
(2.8)\end{array}$ & $\begin{array}{c}8 \cdot 4 \\
(2 \cdot 0)\end{array}$ & $\begin{array}{l}94 \\
(5)\end{array}$ \\
\hline \multicolumn{5}{|l|}{ Cetiedil: } \\
\hline $1 \mu \mathrm{mol} / 1$ & $\begin{array}{c}5 \cdot 9 \\
(2 \cdot 1)\end{array}$ & $\begin{array}{l}13 \cdot 1 \\
(2.9)\end{array}$ & $\begin{array}{c}8.9 \\
(2 \cdot 0)\end{array}$ & $\begin{array}{l}97 \\
(5)\end{array}$ \\
\hline $10 \mu \mathrm{mol} / 1$ & $\begin{array}{l}8 \cdot 4^{*} \\
(2 \cdot 0)\end{array}$ & $\begin{array}{l}8.1^{*} \\
(1.8)\end{array}$ & $\begin{array}{c}8.2 \\
(1.8)\end{array}$ & $\begin{array}{r}110 \\
(6)\end{array}$ \\
\hline $100 \mu \mathrm{mol} / 1$ & $\begin{array}{l}70 \cdot 1^{*} \\
(4 \cdot 9)\end{array}$ & $\begin{array}{l}2 \cdot 1^{*} \\
(0.8)\end{array}$ & $\begin{array}{l}5.0 \\
(0.9)\end{array}$ & $\begin{array}{l}1537^{*} \\
(684)\end{array}$ \\
\hline $500 \mu \mathrm{mol} / 1$ & $\begin{array}{l}99 \cdot 1^{*} \\
(0 \cdot 3)\end{array}$ & $0^{*}$ & $\begin{array}{r}0.8^{*} \\
(0 \cdot 3)\end{array}$ & $\begin{array}{r}11316^{*} \\
(104)\end{array}$ \\
\hline
\end{tabular}

tp $<0.01$ compared with buffer value.

${ }^{*} \mathrm{p}<0.01$ compared with A21387 value.

phology, percentage of irreversibly sickled cells, or haemolysis (table). Cetiedil concentrations of 1,10 , and $100 \mu \mathrm{mol} / 1$ resulted in a significant improvement $(p<0.01)$ in filterability of erythrocytes treated with A23187 after 60 minutes' incubation (fig 2). A concentration of $10 \mu \mathrm{mol} / 1$, however, caused a significant increase in stomatocytes, while $100 \mu \mathrm{mol} / 1$ resulted in $70 \%$ stomatocytes and a 15 -fold increase in haemolysis compared with A23187 alone (table). The highest concentration of cetiedil $(500 \mu \mathrm{mol} / \mathrm{l})$ gave no improvement in filterability compared with A23187 alone, probably because all the cells $(99 \%)$ had become stomatocytic.

\section{Discussion}

Attempts to rehydrate sickle cells by reducing plasma sodium and osmolality are impractical ${ }^{31}{ }^{32}$ but a change in cation flux across the sickle cell membrane to increase the water content of the cell is a more promising approach. Our study shows that at a concentration of $1 \mu \mathrm{mol} / 1$ cetiedil and oxpentifylline produce a significant beneficial effect on the deformability of ionophore dehydrated but oxygenated sickle cells, as measured using a $5 \mu \mathrm{m}$ pore filtration technique. This rheological method, which accords with the guidelines of the International Committee for Standardisation in Haematology, ${ }^{33}$ was designed to simulate erythrocyte flow in the microvasculature and can detect the rheological effect of small amounts of intracellular polymer in sickle erythrocytes at arterial oxygen tension. ${ }^{34}$

Cetiedil is a vasodilator ${ }^{35}$ that enhances passive entry of sodium into erythrocytes ${ }^{1718}$ and decreases potassium loss via the Gardos pathway after calcium loading. ${ }^{1920}$ Both mechanisms could increase cell water, reduce $\mathrm{MCHC}$ and cytoplasmic viscosity, and thus improve erythrocyte deformability. Intravenous cetiedil $(0.4 \mathrm{mg} / \mathrm{kg}$ body weight) has been shown to shorten the duration of vaso-occlusive crisis, ${ }^{21}$ and a single infusion at this dose gives a peak plasma concentration of $0.25 \mu \mathrm{mol} / \mathrm{l}^{36} \mathrm{~A}$ previous in vitro filtration study of deoxygenated sickle cells showed a beneficial effect of cetiedil at 50-200 $\mu \mathrm{mol} / \mathrm{l}$, with no effect on oxygenated cells. ${ }^{37}$ The higher sensitivity of our filtration technique detected an effect on oxygenated SS cells treated with ionophore at $1 \mu \mathrm{mol} / 1$, the lowest concentration studied. At $100 \mu \mathrm{mol} / 1$ and above, the drug caused substantial cell swelling (stomatoxytosis) and haemolysis, as previously reported. ${ }^{1718}$

Oxpentifylline has recently been shown to reduce loss of potassium and therefore water from normal erythrocytes that had been loaded with calcium using the ionophore A23187 or when dehydrated by other ionophores (valinomycin and nystatin). ${ }^{16}$ In that study the dehydration was associated with an increase in $\mathrm{MCHC}$, which was partially prevented by oxo pentifylline. In the present study oxpentifylline significantly improved the filterability of dehydrate sickle cells at a concentration $(1 \mu \mathrm{mol} / \mathrm{l})$ close to that $(0.43 \mu \mathrm{mol} / \mathrm{l})$ achieved in plasma after ingestion of one $400 \mathrm{mg}$ tablet. ${ }^{38}$ This contrasts with a concentration of $5 \mathrm{mmol} / \mathrm{l}$ required to improve the filterability of normal (AA) cells dehydrated by exposure to this calcium ionophore for 60 minutes. ${ }^{16}$

It is difficult to show the action of drugs that change cation flux across membranes when there is no induced change in flux. Previous workers have stressed sickle cells by deoxygenation, ${ }^{37}$ recurring cycles of deoxygenation-reoxygenation, ${ }^{39}$ or depletion of adenosine triphosphate and calcium loading ${ }^{19}$ to show the in vitro effect of antisickling drugs. Our in vitro model was designed to investigate the protective rheological effect of oxpentifylline and cetiedil when added to sickle cells 15 minutes before they underwent loss of cation and water induced by a calcium ionophore. In the absence of this induced flux neither drug improved the filterability of sickle cells; cetiedil (100 and $500 \mu \mathrm{mol} / \mathrm{l})$, in fact, impaired filterability further owing to the formation of stomatocytes. Thus the main therapeutic potential of these drugs lies in the prevention of cation and water loss from sickle cells when they are exposed in vivo to stresses such as deoxygenation, calcium loading, low $\mathrm{pH}$ or hyperosmolality. 
The rheologically beneficial effect of oxpentifylline on sickle cells was, unlike that of cetiedil, independent of change in cell shape, and neither stomatocytosis nor haemolysis were seen at concentrations up to and including $500 \mu \mathrm{mol} / \mathrm{l}$. This accords with the clinical experience of low toxicity of the drug in the long term treatment of atherosclerotic vascular disease. Although one cannot extrapolate from an in vitro effect on cells treated with an ionophore at $1 \mu \mathrm{mol} / \mathrm{l}$ to a rheological effect in vivo, there have been three longitudinal case reports of individual patients who showed an improvement in the filterability of their sickle cells during treatment with oral oxpentifylline. ${ }^{40-42}$ Clinical benefit obtained with oxpentifylline has been reported in four sickle cell patients with recurrent priapism but not in five patients with painful crises. ${ }^{43}$ Controlled trials of oral prophylaxis are now indicated, but careful rheological as well as clinical monitoring will be required as partial rehydration of dense sickle cells could improve their otherwise short survival time and thereby cause transient rheological deterioration.

Further studies of the cation sparing actions of oxpentifylline and cetiedil on the erythrocyte membrane are required, but the demonstration of a beneficial effect on the deformability of stressed sickle cells at a drug concentration of $1 \mu \mathrm{mol} / 1$ indicates the potential of sickle cell "hydrotherapy" for improving blood rheology in this disease.

We are indebted to the Central Birmingham Health District Endowment Research Fund and Hoechst AG for research grants to cover running costs; to Action Research for the Crippled Child for a research training fellowship to AJK; and to Dr IM Franklin for providing access to patients under his care. Oxpentifylline (Trental) and cetiedil citrate (Stratene) for in vitro use were supplied by Hoechst AG, Wiesbaden, West Germany and Laboratoires Innothéra, Arcueil, France, respectively.

\section{References}

1 Clark MR, Unger RC, Shonet SB. Monovalent cation composition and ATP and lipid content of irreversibly sickled cells. Blood 1978;51:1169-78.

2 Masys DR, Bromberg PA, Balcerzak SP. Red cells shrink during sickling. Blood 1974;44:885-9.

3 Glader BE, Nathan DG. Cation permeability alterations during sickling: relationship to cation composition and cellular hydration of irreversibly sickled cells. Blood 1978;51:983-9.

4 Fabry ME, Nagel RL. The effect of deoxygenation on red cell density: significance for the pathophysiology of sickle cell anemia. Blood 1982;60:1370-7.

5 Hofrichter J, Ross PD, Eaton WA. Kinetics and mechanism of deoxyhemoglobin $S$ gelation: a new approach to understanding sickle cell disease. Proc Natl Acad Sci USA 1974;71:4864-8.

6 Noguchi CT, Torchia DA, Schechter AN. Intracellular polymerization of sickle hemoglobin. Effects of cell heterogeneity. $J$ Clin Invest 1983;72:846-52.
7 Mohandas N, Rossi ME, Clark MR. Association between morphologic distortion of sickle cells and deoxygenation-induced cation permeability increase. Blood 1986;68:450-4.

$8 \mathrm{Gardos} \mathrm{G}$. The role of calcium in the potassium permeability of human erythrocytes. Acta Physiol Hung 1959;15:121-5.

9 Bookchin RM, Ortiz OE, Lew VL. Red cell calcium transport and mechanisms of dehydration in sickle cell anemia. In: Beuzard Y, Charache S, Galacteros F, eds. Approaches to the therapy of sickle cell anaemia. Paris: Les Editions INSERM, 1986:291-9.

10 Ellory JC, Hall AC, Stewart GW. Volume-senstivie cation fluxes in mammalian red cells. Molecular Physiology 1985;8:235-46.

11 Brugnara C, Bunn HF, Tosteson DC. Regulation of erythrocyte cation and water content in sickle cell anemia. Science 1986;232:388-90.

12 Clark MR, Mohandas N, Shohet SB. Deformability of oxygenated irreversibly sickled cells. J Clin Invest 1980;65:189-96.

13 Evans E, Mohandas N, Leung A. Static and dynamic rigidities of normal and sickle erythrocytes. Major influence of cell hemoglobin concentration. J Clin Invest 1984;73:477-88.

14 Gulley ML, Ross DW, Feo C, Orringer EP. The effect of cell hydration on the deformability of normal and sickle erythrocytes. Am J Hematol 1982;13:283-91.

15 Porter JM, Cutler BS, Lee BY, et al. Pentoxifylline efficacy in the treatment of intermittent claudication: multicenter controlled double-blind trial with objective assessment of chronic occlusive arterial disease patients. Am Heart J 1982;104:66-72.

16 Bilto YY, Player M, West MJ, Ellory JC, Stuart J. Effects of oxpentifylline on erythrocyte cation content, hydration, and deformability. Clin Hemorheol 1987;7:561-77.

17 Schmidt WF, Asakura T, Schwartz E. The effect of cetiedil on red cell membrane permeability. Blood Cells 1982;8:289-98.

18 Schmidt WF, Asakura T, Schwartz E. Effect of cetiedil on cation and water movements in erythrocytes. $J$ Clin Invest 1982;69:589-94.

19 Berkowitz LR, Orringer EP. Effect of cetiedil, an in vitro antisickling agent, on erythrocyte membrane cation permeability. $J$ Clin Invest 1981;68:1215-20.

20 Berkowitz LR, Orringer EP. An analysis of the mechanism by which cetiedil inhibits the Gardos phenomenon. Am J Hematol 1984;17:217-23.

21 Benjamin L, Berkowitz LR, Orringer E, et al. A collaborative, double-blind randomized study of cetiedil citrate in sickle cell crisis. Blood 1986;67:1442-7.

22 Stuart J, Stone PCW, Bareford D, Caldwell NM, Davies JE, Baar S. Evaluation of leucocyte removal methods for studies of erythrocyte deformability. Clin Hemorheol 1985;5:137-47.

23 Kenny MW, Meakin M, Stuart J. Methods for removal of leucocytes and platelets prior to study of erythrocyte deformability. Clin Hemorheol 1983;3:191-200.

24 Baar S, Bareford D, Keidan AJ, Stone PCW, Stuart J. Elimination of leucocyte artefacts from erythrocyte filtration tests. Clin Hemorheol 1985;6:127-36.

25 Keidan AJ, Sowter MC, Marwah SS, Johnson CS, Stuart J. Evaluation of HEPES and phosphate buffers for rheological studies of sickle cells. Clin Hemorheol 1987;7:599-610.

26 Stuart J, Stone PCW, Bareford D, Bilto YY. Effect of pore diameter and cell volume on erythrocyte filterability. Clin Hemorheol 1985;5:449-61.

27 Reinhart WH, Chien S. Roles of cell geometry and cellular viscosity in red cell passage through narrow pores. Am J Physiol 1985;248:C473-9.

28 Bilto YY, Stuart J. Ultrasonic cleaning of polycarbonate membranes for measurement of erythrocyte filterability. Clin Hemorheol 1985;5:437-48.

29 Bessis M. Red cell shapes. An illustrated classification and its rationale. Nouv Rev Fr Hematol 1972;12:721-46.

30 Clark MR, Mohandas N, Embury SH, Lubin BH. A simple laboratory alternative to irreversibly sickled cell (ISC) counts. Blood 1982;60:659-62. 
31 Charache S, Walker WG. Failure of demopressin to lower serum sodium or prevent crisis in patients with sickle cell anemia. Blood 1981;58:892-6.

32 Leary $\mathbf{M}, \mathbf{A b r a m s o n} \mathbf{N}$. Induced hyponatremia for sickle cell crisis. N Engl J Med 1981;304:844-5.

33 International Committee for Standardisation in Haematology (Expert Panel on Blood Rheology). Guidelines for measurement of blood viscosity and erythrocyte deformability. Clin Hemorheol 1986;6:439-53.

34 Green MA, Noguchi CT, Marwah SS, Keidan AJ, Stuart J. Polymerization of hemoglobin $S$ and loss of sickle erythrocyte deformability at arterial oxygen saturation. Blood 1986;68 (suppl 1):62a.

35 Simaan JA, Aviado DM. A comparative study between cardiovascular effects of cetiedil, a new vasodilator, and papaverine and aminophylline. J Pharmacol Exp Ther 1976;198:176-86.

36 Orringer EP, Powell JR, Cross RE, et al. A single-dose pharmacokinetic study of the antisickling agent cetiedil. Clin Pharma col Ther 1986;39:276-81.

37 Benjamin LJ, Kokkini G, Peterson CM. Cetiedil: its potentia usefulness in sickle cell disease. Blood 1980;55:265-70.

38 Hinze HJ, Grigoleit HG, Rethy B. Bioavailability and pharmacokinetics of pentoxifylline from "Trental 400" in man. Pharmatherapeutica 1976;1:160-71.
39 Ohnishi ST, Horiuchi KY, Horiuchi K, Jurman ME, Sadanaga KK. Nitrendipine, nifedipine and verapamil inhibit the in vitro formation of irreversibly sickled cells. Pharmacology 1986;32:248-56.

40 Keller F, Leonhardt $\mathrm{H}$. Amelioration of blood viscosity in sickle cell anemia by pentoxifylline. A case report. J Med 1979;10:429-33.

41 Heilmann E, Laage HM, Zimmermann E, Dorst K-G. Medikamentöse Beeinflussung der Erythrozytenflexibilität bei Sichelzellenanämie. Inn Med 1982;9:277-80.

42 Seiffge D, Berthold $R$, Berthold $F$. Effect of pentoxifylline on sickle cell thalassaemia: haemorheological and clinical results. Klin Wochenschr 1983;61:1159-60.

43 Milner PF, McCarty EW. Treatment of vaso-occlusive events in sickle cell anemia with pentoxifylline (Trental). In: Beuzard Y, Charache S, Galacteros F, eds. Approaches to the therapy of sickle cell anaemia. Paris: Les Editions INSERM, 1986:379-83.

Requests for reprints to: Professor J Stuart, Department of Haematology, Medical School, University of Birmingham, Birmingham B15 2TJ, England. 